\title{
1991-1995 Selected Bibliography of Administrative and Technical Communication in Canada
}

\author{
Sheryl Curtis \\ Concordia University
}

\begin{abstract}
Although bibliographies of administrative and technical communication in Canada were once a regular feature in Technostyle, the last one dates back to 1991 (Connor 1991, p.73). This current selected bibliography attempts to list the books and articles pertaining to technical and administrative communication published by, for and about Canadians since that time. The 1991 Technostyle bibliography served as a starting point for this one, and there has been some deliberate overlapping in an effort to create a certain sense of continuity and consistency. I have also chosen to interpret "administrative and technical communication" in the broadest of senses, much like J.J. Connor who writes, "the academic understanding of 'technical communication' has embraced related subjects in administrative and business communication, translation, education, linguistics, engineering, law, medicine, and others" (Connor 1994, p. 353).
\end{abstract}

ENTRIES FOR THIS BIBLIOGRAPHY WERE RESEARCHED in a variety of journals and databases. Considering the scope of the material included in this bibliography, no effort has been made to attempt any form of synthesis. Obviously, the process of building a bibliography could be considered akin to searching for a needle in a haystack. It is not always easy to track down authors and determine whether they are actually Canadian. At the same time, complete bibliographic entries have not always been available. Any entries which remained unconfirmed or incomplete have been excluded. At the same time, this process is also highly personal since it would be impossible to discern what exactly would be of interest to all readers of Technostyle and to please all of the people all of the time, so to speak. Finally, this process 
is most definitely not infallible. Valuable entries may have been missed; other entries may also be valid, despite the lack of confirmation. In this respect, any comments and suggestions will be appreciated.

Auger, P., Drouin, P. \& L'Homme, M.-C. (1991). Automatisation des procédures de travail en terminographie. Meta, 36(1), $121-27$.

Baker, L. M. \& Connor, J.J. (1994). Physician-patient communication from the perspective of Library and Information Science. Bulletin of the Medical Library Association, 82(1), $36-43$.

Beaudet, C. (1994). Pour une typologie des résumés fonctionnels : réflexion sur l'acte de classification. Technostyle, 11(3/4), 49 - 58.

. (1995). Le rapport annuel: un discours argumentatif et performatif. Technostyle, 12(2), $25-35$.

Bédard, C. (1992). La prétraduction automatique, outil de productivité et d'évolution professionnelle. Meta, 37(4), 738 - 760.

Begoray, D. (1995). Le Penseur meets L'Entrepreneur: Pushing the envelope of ethnography in business writing research. Technostyle, 12(2), 37 - 48.

Bist, G. (1994). Single-source manuals. IEEE Transactions on Professional Communication, 37(2), $81-87$. (1995). Testing examples: A guide. Technical Communication, 42(1), $84-94$.

Bist, G., K Dixon, \& Chadwick, G. (1993). Setting up a customer network to review documentation. Technical Communication, 40(4), 715 - 719.

Blicq, R.S. (1991). Communicating at work: Creating messages that get results. Scarborough: Prentice-Hall Canada. . (1992). Technically-write! communicating in a technological era. (Canadian 4th ed.). Scarborough: Prentice-Hall Canada.

Bogdanowicz, M.S. (1992). The communication audit: Information flow and the organization. Technostyle, 10(1), 1 - 10.

Bossé-Andrieu, J. (1991). Le recul du français comme langue des sciences. Technostyle, 9(2), $20-41$. 
. (1993). La question de la lisibilité dans les pays anglophones et les pays francophones. Technostyle, 11(2), $73-85$.

(1994). Le poids de trois siècles de normativisme linguistique.

Technostyle, 11(3/4), 1 - 15.

Bossé-Andrieu, J., Cajolet-Laganière, H. \& Russell, P. (1994). La rédaction professionnelle en français au Canada: résultats d'une enquête. Joumal of Technical Writing and Communication, 24(3), 251 - 264.

Boulanger, J.-C. \& L'Homme, M.-C. (1991). Les technolectes dans la pratique dictionnarique générale : quelques fragments d'une culture. Meta, 36(1), $23-40$.

Boutry, P. \& Contant, L. (1991). Contrôler la qualité, ce n'est pas "nécessairement" réviser. Circuit, 35 (December), 4 - 5.

Buchan, R. (1992). Corporate culture and writing: The evolution of the written document. Technostyle, 10(1), $11-22$.

Cajolet-Laganière, H., Collinge, P. \& Langanière, G. (1993). Rédaction technique et administrative. Sherbrooke: Éditions Langanière.

Carey, J., Dupont, S. \& Leonhardt, C. (1991). Termium sur CD-ROM. Meta, $36(1), 174-181$.

Cherry, J.M. (1992). Improving subject access in OPACs: An exploratory study of conversion of users' queries. Joumal of Academic Librarianship, $18(2), 95-99$. . (1992). OPACs at 5 Ontario universities: A profile of user and user satisfaction. Canadian Library Joumal, 49(2), 123 - 132.

Cherry, J.M. \& Clinton, M. (1994). Evaluating the effectiveness of a conceptbased computer tutorial for OPAC users. College $\mathcal{E}$ Research Libraries, $55(4), 355-364$.

Cherry, J.M., Williamson, N.J. \& Gu, Zin (1994). OPACs in twelve Canadian academic libraries: An evaluation of functional capabilities and interface features. Information Technology and Libraries, 13(3), $174-196$.

Collins, C.E. (1991). The Basics of technical writing and speaking. Scarborough: Prentice-Hall Canada. 
Communications: Technical writers and trainers. (1995, November 20). McLean's, 55.

Connor, J.J. (1991). History and the study of technical communication in Canada and the United States. IEEE Transactions on Professional Communication, 34(March), 3 - 6. . (1991). 1991-1992 Annual bibliography of administrative and technical communication in Canada. Technostyle, 9(2), 73. . (1991). 1989-1990 Annual bibliography of administrative and technical communication in Canada. Technostyle, 9(2), $69-72$. . (1993). Medical text and historical context: Research issues and methods in history and technical communication. Journal of Technical Writing and Communication, 23(3), $211-232$.

. (1994). Reflections/directions in technical communication in Canada: A panel discussion. Technostyle, 11(3/4), 139 - 162.

. (1994). Research on technical and scientific communication in Canada: A bibliographic odyssey. Joumal of Technical Writing and Communication, 24(3), $353-361$.

. (1994). Self-help medical literature in 19th Century Canada and the rhetorical convention of plain language. Journal of Technical Writing and Communication, 24(3), 265 - 284.

. (1994). The culture of experience and the culture of noesis:

Thoughts on the history and future of CATTW/ACPRTS. Technostyle, $11(3 / 4), 163-169$.

. (1995). The Canadian medical book in the 19th Century. $A b$ Bookman's Weekly, 95(18), 1934 et seq.

Connor, J.J. \& Connor, T.H.J. (1994). Semantic bypassing in technical Communication: The historical case of antiseptics. Technostyle, 11(3/4), $59-69$.

Connor, J.T.H. \& Connor, J.J. (1992). Commentary on rhetorical analyses of William Harvey's De Motu Cordia (1628). Journal of Technical Writing and Communication, 22(2), $195-202$. 
Corbeil, J.-C. (1991). Terminologie et banques de données d'information scientifique et technique. Meta, 36(1), 128 - 134.

Cormier, M. (1991). Evaluation of MT systems. Language Intemational, $3(4), 8$.

. (1991). Traduction de textes destinés à des spécialistes : approche pédagogique. Meta, 36(2/3), 442 - 447.

Cormier, M.C. \& Rioux, L.-P. (1991). Procédés de formation et matrices terminogéniques en terminologie des systèmes experts. Meta, 36(1), $248-263$.

Cornibert, G. (1991). Lettre ouverte aux gestionnaires de services linguistiques: une question de survie. Circuit, 35 (December), 3 - 4 .

Courtis, J.K. (1992). The reliability of perception-based annual report disclosure studies. Accounting and Business Research, 23(89), 31 - 43.

. (1995). JIT's impact on a firm's financial statements. International Joumal of Purchasing and Material, 31(1), 45 et seq.

Couture, B. (1992). Categorizing professional discourse: Engineering, administrative, and technical/professional writing. Joumal of Business and Technical Communication, 6(1), 5 - 37 .

. (1993). Against relativism: Restoring truth in writing. Journal of Advanced Composition, 13(1), 111 et seq.

Crawford, S. (1995). Writing errors of ESL engineering students: A diagnostic analysis. Technostyle, 12(2), $77-85$.

Crowley, G. (1991). The fiction of the "real" reader: A comparison of audience perception experienced by college students and business people. Technostyle, 9(3), 1 - 17 .

Dancette, J. (1991). Les opérations de compréhension préalables à la production de métatextes: recherche d'une typologie. Revue Belge de philologie et d'histoire, 69(3), $563-575$.

(1992). Modules sémantique et propositionnel de l'analyse de la fidelité en traduction. Meta, 37(3), 440-449.

Doray, F.\& Gaudet, R. (1991). La recherche thématique à Hydro-Québec. Meta, 36(1), 243 - 247. 
Dowhal, D. et al. (1993) Producing a video on a technical subject: A guide. IEEE Transactions on Professional Communication, 36(2), 62 - 69.

Dowler, M. \& McEvoy, C. (1992). Checking the checkers: Computer editing packages. Technostyle, 10(2), 19-29.

Emery, P.G. (1991). Text classification and text analysis in advanced translation teaching. Meta, 36(4), $567-577$.

Freedman, A., Adam, V \& Smart, G. (1994). Wearing suits to class:

Simulating genres and simulations as genre. Written Communication, 11(2), $193-226$.

Gémar, J.-C. (1991). Terminologie, langue et discours juridiques : sens et signification du langage du droit. Meta, 36(1), 275 - 283.

Giltrow, J. (1992). Using a pragmatic concept of background knowledge to analyze the technical audience. Technostyle, 10(1), 23- 57.

. (1993). Review of Textual carnivals: The politics of composition by S.

Miller, published by the Southern Illinois University Press. Technostyle, 11(2), 103 - 108.

. (1995). Review of Writing science: Literacy and discursive power by M.A.K. Halliday and J.R. Martin, published by University of Pittsburgh Press in 1993. Technostyle, 12(1), $149-155$.

Goodwin, D. (1991). Emplotting the reader: Motivation and technical documentation. Journal of Technical Writing and Communication, 21(2), 99 115.

. (1994). Designing a quick reference guide: A teaching case. Journal of Technical Writing and Communication, 24(3), 293 - 308.

Graves, R., McFadden, J. \& Moore, S. (1994). Technical communication programs at Canadian post-secondary institutions. Journal of Technical Writing and Communication, 24(3), 237 - 250.

Harris, R.A. (1991). A do-it-yourself usability kit.Joumal of Technical Writing and Communication, 22 (4), 351-250.

. (1992). Commentary: A response to K. Scott Ferguson and F.

Parker's 'Grammar and Technical Writing'. Joumal of Technical Writing and Communication, 22(1), 53 - 56 . 
Harris, R.A. \& Hosier, W.J. (1991). A taxonomy of online information. Technical Communication, 38(2), $197-210$.

Harris, R.\& Russell, P. (1994). Special issue: Technical communication in Canada. Joumal of Technical Writing and Communication, 24(3).

Horn, C. (1994). Reading the bureaucratic text: Analysis and committee documents. Technostyle, 11(3/4), $71-93$.

. (1995). Chiropractic discourse: Adjusting spines, locating subjects. Technostyle, 12(1), 45 - 66 .

Isabelle, P. (1992). La bi-textualité : vers une nouvelle génération d'aides à la traduction et la terminologie. Meta, 37(4), 721 - 737.

Jackson, S. et al (1992). On-line scenario-based task help. IEEE Transactions on Professional Communication, 35(2), $91-97$.

Jordan, M.P. (1991). An integrated three-pronged analysis of a fundraising letter. In W.C. Mann and S.A. Thompson (Eds.), Discourse Description of a Fund-Raising Letter. Amsterdam: John Benjamins.

. (1991). The genre of technical abstracts. In A. Della Volpe (Ed.), The 17th LACUS Forum (pp. 507 - 527). Lake Bluff, Ill.: Linguistic Association of Canada and the United States. . (1991). Openings in informal scientific texts. Technostyle, 9(2), 1 - 9. (1991). Openings in quite formal scientific texts. Technostyle, 9(3), $18-37$.

. (1992). Beyond impressionism: Evaluating causal connections. In B. Fearing, \& K. Sparrow (Eds.), Advanced Technical Writing: Theor $y$ and Practice (pp. 102-114). New York: MLA.

. (1993). Openings in very formal technical texts. Technostyle, 11(1), $1-28$.

. (1993). Towards an understanding of mature writing: Analyzing and paraphrasing complex noun phrases. Technostyle, 11(2), $39-72$.

(1994). Toward plain language: A guide to paraphrasing complex noun phrases. Joumal of Technical Writing and Communication, 24(1), $77-96$. 
. (1994). Plainer legal language: Definitions and requirements in acts. Journal of Technical Writing and Communication, 24(3), 333 - 352.

. (1995). The practices of technical writing: Bridging the culture gaps. Technostyle, 12(1), 145 - 148.

- (1995). The evolution of the genre of Canadian acts: Sentence structure and complexity. Technostyle, 12(1), $117-143$.

Kanaganayakam, C. (1991). Text and subtext in designing hands-on course notes. Technostyle, 9 (2) $42-56$.

Karis, W. (1991). Collaborating with readers: Empower them and take the consequences. Technical Communication, 38(4), 513 - 519.

Kerpan, N. (1991). La vulgarisation technique dans l'entreprise. Technostyle, 9(2), 57-68.

. (1991). Temps forts ou temps faibles pour la terminologie en entreprise. Meta, 36(1), 234-239.

Laduc, L. (1991). Infusing practical wisdom into persuasion performance: Hermeneutics and the teaching of sales proposal writing. Joumal of Technical Writing and Communication, 21(2), 155-180.

Laduc, L. \& Goldrick-Jones, A. (1994). The critical eye, the gendered lens, and situated insights - feminist contributions to professional communications. Technical Communication Quarterly, 3(3), 245 - 256.

Lambert, S. (1991). Aptitude testing for simultaneous interpretation at the University of Ottawa. Meta, 36(4), 586 - 594. . (1992). Shadowing. Meta, 37(2), $263-273$.

Larivière, L. (1993). Review of La rédaction de rapports : structure des textes et stratégie de communication by R. Larose, published by Presses de l'Université du Québec in 1992. Technostyle, 11(1), 37-40.

. (1993). Review of La rédaction de rapports : structure des textes et stratégie de communication : Cahier d'exercices by R. Larose, published by Presses de l'Université du Québec in 1992. Technostyle, 11(1), $37-40$. 
(1995). Situation de la rédaction professionelle dans l'entreprise : IRésultats d'une enquête effectuée, en 1992, auprès de 26 entreprises (Sociétés d'état et Sociétés commerciales publiques et privées situées dans la région montréalaise). Technostyle, 12(1), 67-98.

Larose, R. (1992). La rédaction de rapports : structure des textes et stratégie de communication. Québec: Presses de l'Université du Québec.

. (1992). La rédaction de rapports : structure des textes et stratégie de communication: Cahier d'exercices. Québec: Presses de l'Université du Québec.

Ledwell-Brown, J. \& Dias, P. (1994). The way we do things here: The significance of narratives in research interviews. Journal of Business and Technical Communication, 8(2), 165 - 185.

Lethuillier, J. \& Cormier, M.C. (1991). Combinatoire, terminologie et textes. Meta, 36(1), $92-100$.

. (1993). Terminologie comparée anglais-français de la vision par ordinateur et des sujets connexes - première partie. Meta, 38(2), $302-331$.

Loffler-Laurian, A.-M. (1994). Explications scientifiques bilingues: différences linguistiques ou culturelles? Circuit,43 (March), 5-6.

McDaniel, B. (1994). The role of contrastive rhetoric in teaching professional communication in English as a second or foreign language. IEEE Transactions on Professional Communication, 37(1), 29 - 33.

Meney, L. (1993). Un exercise de rédaction : la contraction de texte. Technostyle, 11(2), 18 - 38. . (1994). Pour une typologie des anglicismes en français du Canada. French Review, 67(6), 930 - 943.

Murphy, A.J. (1995). Books about the Internet: Help for the technical communicator cybersurfer. Technical Communication, 42(2), 290-302.

Parker, A. (1992). Implementing collaborative projects in the technical writing classroom. Technostyle, 10(2), $30-48$. 
(1995). Evaluating collaborative projects and evaluation tools:

Putting the pieces of the collaborative puzzle together. Technostyle, 12(1), $99-115$.

Pavel, S. (1994). Écrire dans un monde de plus en plus spécialisé. Circuit, 43 (March), 2-3.

Pavelich, J. \& Jordan, M. (1994). The Canadian Association of Teachers of Technical Writing: Its early history. Technostyle, 11(3/4), $131-137$.

Proulx, M. (1994). Traduction de logiciels : mission possible! Circuit, 43 (March), 11 - 13.

Read, H.\& Collins, C.E. (1991). English at work: Communicating in business and industry. Scarborough: Prentice-Hall Canada.

Reinsch, N.L. (Jr.) \& Beswick, R. W. (1995). Preferences for sending wordprocessed versus handwritten messages: An explanatory study. Joumal of Business and Technical Communication, 9(1), 42 - 62 .

Roberts, J., Scarry, J. \& Scarry, S. (1994). The Canadian writer's workplace. (2nd ed.). Toronto: Harcourt Brace.

Rockley, A. (1993). Ontario Hydro and SGML. Technical Communication, $40(3), 383-386$.

. (1994). Planning a multimedia documentation project. Technical Communication, 41(4), 653 - 661 .

Rodman, L. (1991). Anticipatory It in scientific discourse. Joumal of Technical Writing and Communication, 21(1), $17-27$.

. (1991). Technical communication: Strategy and process. Toronto: Harcourt Brace Jovanovitch, Canada.

. (1993). Review of Essentials of writing biomedical research papers by M. Zeiger, published by McGraw-Hill in 1991. Technostyle, 11(1), $33-36$.

. (1994). The active voice in scientific articles: Frequency and discourse functions. Joumal of Technical Writing and Communication, 24(3), $309-332$. 
. (1995). Review of Writing in the workplace: New research perspectives by R. Spilka, published by Southern Illinois University Press in 1993. Technostyle, 12(2), 87-91.

Rouleau, M. (1991). "Adverse effect" est-il synonyme de "side effect"? Meta, $36(2 / 3), 497-507$.

. (1993). Des traquenards de la version médicale I. Action, effect, potency et effectiveness. Meta, 38(2), 268 - 274.

. (1993). La voix passive dans les textes médicaux et para-médicaux. Meta, 38(3), $440-448$.

Rousseau, L.-J. (1991). La pratique québécoise de la normalisation terminologique. Meta, 36(1), $225-230$.

Russell, P. (1993). Evaluation: A holistic approach. Technostyle, 11(2), 86 - 97. (1994). Investigating summary typology: Considerations for classification. Technostyle, 11(3/4), $37-47$.

Russell, P., Bossé-Andrieu, J. \& Cajolet-Laganière, H. (1995). Technical writing in French in Canada: Results of two surveys. Technostyle, 12(2), $49-75$.

Sanderson, L. (1995). Linguistic contradiction: Power and politeness in courtroom discourse. Technostyle, 12(2), 1 - 24.

Saunders, P. (1991). Deconstructing the academic process in technical writing. Technostyle, 9(3), 38-50.

. (1992). Strategy: Writing at work. Toronto: HBJ Holt Canada.

Schryer, C. (1994). Journeying through paralysis to praxis: Teaching professional writing with Bourdieu and Williams. Technostyle, 11(3/4), $111-129$.

Schryer, C.F. (1993). Records as genre. Written Communication, 10(2), $200-234$.

. (1993). Review of Technical communication: Strategy and process by L. Rodman, published by Harcourt Brace Jovanovitch in 1991. Technostyle, 11(1), $29-31$. 
(1994). The Lab vs. the clinic: Sites of competing genres. In A.

Freedman \& P. Medway (Eds.), Genre and the new rhetoric. London: Taylor \& Francis.

Segal, J.Z. (1993). Writing and medicine: Text and context. In R. Spilka (Ed.), Writing in the workplace: New research perspectives (pp. 84 - 97). Carbondale, Ill.: Southern Illinois University Press.

. (1993). Strategies of influence in medical authorship. Social Science and Medicine, 37(4), $521-30$.

Séguinot, C. (1992). Where angels fear to tread. Language Intermational, 4(4), 40 et seq.

. (1994). Technical writing and translation: Changing with the times. Journal of Technical Writing and Communication, 24(3), 285-292.

Shand, R.M. (1994). User manuals as project manual tools: Part I theoretical background. IEEE Transactions on Professional Communication, $37(2), 75-80$.

Sole, T.D.\& Bist, G. (1991). The design document: Key to managing documentation development. IEEE Transactions on Professional Communication, 34(2), $70-74$.

. (1995). Benchmarking in technical information. IEEE Transactions on Professional Communication, 38(2), 77 - 82.

Stewart, K.L. \& Kowler, M. (1991). Forms of writing: A brief guide and handbook. Scarborough: Prentice-Hall Canada.

Valiquette, M. (1991). Lexique anglais-français de neurochirurgie. Meta, $36(4), 633-644$.

Verrier, D. (1991). Gestionnaires de services linguistiques: à vos pupitres! Circuit, 35 (December), 3.

Viau, R. \& Larivee, J. (1993). Learning tools with hypertext: An experiment. Computers and Education, 20(1), $11-16$.

Wegner, D. (1992). Classroom instruction and workplace practice: Values that shape teaching and performance standards. Technostyle, 10(2), $1-18$. . (1993). Review of Clear and coherent prose: A functional approach by W. Vande Kopple, published by Scott, Foresman and Company in 1989. Technostyle, 11(2), $98-103$. 